lijne. $\mathrm{Z}$ drugiej jednak strony, są one w jakiś sposób obecne w innych artykułach, szczególnie dotyczących augustyńskich komentarzy do Pisma św. Być może warto pogłębić niektóre noty, czy zaopatrzyć je w obfitszą bibliografię. Spotykamy np. intrygująco brzmiący tytuł Augustyn w cyberprzestrzeni. Spodziewać się w nim możemy szczegółowych odnośników, adresów internetowych, tymczasem napotykamy na bardzo ogólne opracowanie. Można jakoś usprawiedliwiać autora amerykańskiego, który pisał swój artykuł kilka lat temu, ale redaktorzy wersji hiszpańskiej mogli pomyśleć o jego uzupełnieniu. Być może można też dodać opracowania jeszcze kilku tematów, ale uczynienie tego spowodowałoby nadmierny rozrost książki, która i tak liczy prawie półtora tysiąca stron, oraz otworzenie perspektyw, które znowu domagałyby się tworzenia kolejnych haseł.

Nieliczne negatywy nikną jednak w świetle dogłębnie przemyślanej całości. Słownik jawi się metodycznie opracowanym dziełem, które daje pełen ogląd życia i myśli św. Augustyna oraz jego wpływu na teologię i filozofię. Wypełnia ono lukę pomiędzy wielkimi, często trudno dostępnymi pozycjami w rodzaju Augustinus-Lexicon, a mniejszymi i zbyt ogólnymi - konkretne przykłady pominę - które służą (i bardzo dobrze) raczej pobożnym poszukiwaczom wzorów świętości, niż studentom czy wykładowcom. Powyżej postawiono pytanie o poziom dzieła. Tu można dać odpowiedź jedynie pozytywną. W tym kontekście nie dziwi opinia J. Pelikana, umieszczona w przedmowie Stownika, iż jest dla niego honorem i przyjemnością zarekomendowanie go czytelnikom.

Ks. Jerzy Lachowicz - Białystok

\title{
Leon NIEŚCIOR, Asceza chrześcijańska i filozofia w pismach Nila z Ancyry, Poznań 2001, Uniwersytet im. Adama Mickiewicza w Poznaniu. Wydział Teo- logiczny, ss. 280.
}

Nil z Ancyry należy do tych autorów wczesnochrześcijańskich, których autentyczność niektórych dzieł jest do dziś mocno kwestionowana. Może też dlatego nie cieszył się on w Polsce zbyt wielkim zainteresowaniem wśród badaczy antyku chrześcijańskiego, mimo iż należy niewątpliwie do jednych z największych mistrzów życia duchowego w starożytności na Wschodzie. $\mathrm{Z}$ przekładów jego pism możemy raptem wymienić fragment traktatu $O$ dobrowolnym ubóstwie, anonimowego tłumacza („Szkoła Chrystusowa” 1:1930, t. 1, 85-88), kilkadziesiąt listów w przekładzie prof. L. Małunowiczówny (STCh II 291-323), oraz fragmenty Mowy ascetycznej w tłumaczeniu A. Bobera SJ („Znak” 26:1974, nr 240, 829). Natomiast listę opracowań otwiera właśnie niniejsze studium, które stanowi pierwszy poważny przyczynek naukowy na gruncie polskim na temat mnicha z Ancyry. Ten wykaz zamyka jak dotychczas 
artykuł tego samego autora pt. Filanthrōpia Boga i człowieka w świetle pism Nila z Ancyry (SACh 15:2001, 96-108). Cieszy więc fakt, że dokonania Nila z Ancyry zostały przybliżone szerszemu gronu czytelników, dzięki pracy ks. Leona Nieściora, który już nie pierwszy raz zajmuje się problematyką monastyczną. Wcześniej jednak w centrum jego zainteresowań stał inny wielki mistrz ascezy - Ewagriusz z Pontu. Przejdźmy już jednak do samego dzieła.

$\mathrm{Na}$ jego kompozycję składają się 3 rozdziały, poprzedzone obszernym wprowadzeniem (s. 7-29), a zakończone uwagami końcowymi (s. 235-242) i bogatą bibliografią, zawierającą teksty źródłowe i opracowania (s. 243-266). Nie zaznaczono tutaj jednak, oprócz tłumaczenia L. Małunowiczówny, o wspomnianych wcześniej fragmentach polskich przekładów ze „Szkoły Chrystusowej” i „Znaku”. Warto tutaj zwrócić uwagę, że w wymienionym wstępie bardzo solidnie przeprowadzono krytykę źródeł, dzięki czemu czytelnik ma możność dokładnego zaznajomienia się z zagadnieniem autentyczności dzieł Nila z Ancyry. Autor postawił sobie za cel ambitne zadanie zbadania relacji zachodzących pomiędzy ascezą i filozofią i to nie tylko na płaszczyźnie pojęć, lecz także aretologii. Pierwszym krokiem w realizacji podjętego zadania stało się ustalenie znaczenia tych pojęć w twórczości Nila z Ancyry (rozdz. I). Ks. Nieścior stwierdza więc, że terminy techniczne, które określają ascezę to:

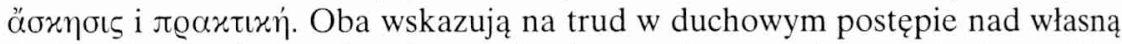
doskonałością, który charakteryzuje się przede wszystkim praktykowaniem aktów pobożności, dzieł cnoty i zachowywaniem przykazań, a następnie kon-

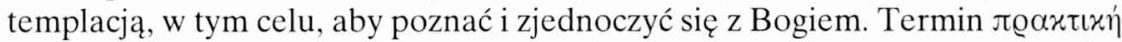
poszerza jednak to znaczenie, bo wskazuje, że ćwiczenia ascetyczne prowadzą do mistycznego oglądania Boga. Uderzające jest to, że termin ten występuje przede wszystkim w pismach Nila zachowanych w języku syryjskim, które ponadto w odróżnieniu od greckich pism charakteryzują się metaforyzmem językowym. Ten fakt, zdaniem ks. Nieściora, wzmacnia jeszcze bardziej tezę różnego autorstwa tych zbiorów. Podobne treści występują w pojęciu $\phi ı \lambda o \sigma o \phi i \alpha$, które łączy się tutaj z ascezą. Filozof to ten, który naśladuje Chrystusa i Apostołów, ćwiczy wyrzeczenie, walkę z namiętnościami, ubóstwo, pokorę, cierpliwość w znoszeniu doświadczeń życiowych i jednocześnie szuka ciszy, samotności i kontemplacji Boga. Tym właśnie różni się od pogańskich filozofów, którzy zagubili tożsamość słowa i czynu. Najlepszym sposobem uprawiania filozofii staje się życie monastyczne, co nie znaczy, że ogranicza się ona tylko do kręgu mnichów. Ostatecznie nasz Autor dochodzi do wniosku, że asceza i filozofia uzupełniają się wzajemnie na płaszczyźnie etycznej, niemniej jednak są to pojęcia autonomiczne. Pierwsze wiąże się raczej z monastycyzmem, a drugie ma bardziej uniwersalny charakter, bo odnosi się do każdego chrześcijanina.

Po dokonaniu takiej ogólnej analizy, ks. Nieścior pyta dalej o związek tych pojęć na płaszczyźnie aretologii (rozdz. II). Do swoich badań wybrał te cnoty, 
które najbardziej wiążą się z ascezą i filozofią, a mianowicie: umiarkowanie, ubóstwo, pokorę, wyciszenie i cierpliwość. W rezultacie wyszukał te filozoficzne i teologiczne przesłanki, które określają sens ascezy. Między nimi zachodzi wzajemna równowaga, do tego stopnia, że płaszczyzna religijna i filozoficzna ascezy jest nierozdzielnie ze sobą związana. Stąd Autor dochodzi do wniosku, że ta Nilowa synteza teologii i filozoficznej antropologii życia ascetycznego „jest bodajże największym jego wkładem w teologię ascetyczną pierwszych wieków" (s. 190). Nil przejął idee mądrościowe swego środowiska i połączył je z myślą chrześcijańską, szczególnie zaś na płaszczyźnie refleksji psychologicznej inspirowanej stoicyzmem. Od strony filozoficzno-antropologicznej asceza jest motywowana argumentem etycznej doskonałości, psychologicznej strategii walki przeciw namiętnościom gnostyckiej politei, postępowania zgodnego z naturą. Stąd też bierze się pewien rys humanistyczny ascezy, której celem staje się nie tylko zjednoczenie z Bogiem, ale również ogólny pożytek człowieka. Nie ma w niej miejsca na przesadne rygoryzmy, wiąże się natomiast z roztropnością i życiem apostolskim. Od strony teologicznej natomiast pojawiają się u Nila prawie wszystkie typowe motywy dla greckiej duchowości, jak miłość Boża, naśladowanie Chrystusa i Apostołów, powrót do pierwotnego stanu Adama, walka z demonami, Boże poznanie, anielskie życie, przyjęcie darów Ducha Świętego, wieczna nagroda i połączenie z Bogiem. Autor podkreśla jednak, że między filozoficzną i teologiczną argumentacją istnieje swoista równowaga.

Nil z Ancyry nie jest oryginalny w swej nauce. Daje się u niego stwierdzić pewną zależność od swoich poprzedników. To zagadnienie stało się przedmiotem badań ostatniej części naszej książki (rozdz. III). Ksiądz Nieścior dochodzi do wniosku, że filozoficzny etos Nila z Ancyry ma wspólne cechy z nauczaniem Ojców Kapadockich, i przede wszystkim Jana Chryzostoma. Nie chodzi tylko o ogólne wspólne rozumienie pojęć, ale także o szczegółowy program chrześcijańskiego życia, który jest taki sam w obu filozofiach. Różnica zachodzi jedynie w tym, że Nil aplikuje pojęcie „filozofii” raczej do życia eremickiego, podczas gdy Jan Chryzostom odnosi ją do życia ascetycznego w mieście, co z pewnością wiąże się z jego duszpasterską posługą biskupią.

U Nila z Ancyry dostrzec można również zależności od pisarzy niechrześcijańskich, które trzeba rozpatrywać integralnie z duchem epoki. Początek V wieku był bowiem czasem dyfuzji między hellenistyczną i chrześcijańską etyką. Kościelni pisarze tej epoki przejęli wiele ze świeckiej literatury poprzednich wieków. Takie punkty styczności można znaleźć np. w nauce Nila i stoickiego filozofa Epikteta. Potwierdzają one, zdaniem naszego Autora, tezę o rozległej inkulturacji chrześcijaństwa w początkach epoki bizantyńskiej.

Otrzymaliśmy więc opracowanie jasne i przejrzyste w swej treści. Zachwyca w nim solidność w posługiwaniu się aparatem krytyczno-naukowym, jak też rzetelne wykorzystanie bogatego materiału bibliograficznego, który jeszcze 
bardziej świadczy o olbrzymich zaległościach naszej rodzimej patrologii w tej dziedzinie. Autor prowadzi swoje rozważania klarownie i metodycznie, dzięki czemu czytelnik może swobodnie śledzić myśl autora. Odpowiednie polskie terminy są zilustrowane greckimi odpowiednikami, co pozwala na lepszą orientację w niełatwych przecież zagadnieniach, a przy tym nie ma zbędnego nagromadzenia tekstów oryginalnych, co ostatnio często staje się udziałem niektórych polskich patrologów. Nie uniknięto oczywiście drobnych potknięć literowych, jak np. $\sigma \omega \mu \tau \iota x \tilde{\eta} \varsigma$ zamiast $\sigma \omega \mu \alpha \tau \iota x \tilde{\eta} \varsigma$ (s. 32), czy też błędów rzeczowych, jak przypisanie Józefowi Egipskiemu, że był namawiany do popełnienia czynu nieczystego przez żonę faraona (s. 85), gdy tymczasem była to małżonka Potifara, urzędnika faraona (por. $\mathrm{Wj} 39,7 \mathrm{n}$ ). Są to jednak tylko drobne niedociągnięcia, które w niczym nie umniejszają wartości niniejszej pracy. Wydaje się, że każdy czytelnik może znaleźć tutaj coś dla siebie i zaczerpnąć z bogatej myśli Nila z Ancyry w celu ubogacenia własnej duchowości.

Józef Figiel SDS - Lublin, KUL

Krzysztof STOPKA, Armenia Christiana. Unionistyczna polityka Konstatynopola i Rzymu a tożsamość chrześcijaństwa ormiańskiego (IV-XV w.). Rozprawy Wydziału Historyczno-Filozoficznego zbioru ogólnego tom 96, Kraków 2002, Polska Akademia Umiejętności, ss. 354.

Jest to niewątpliwie najlepsza $z$ dotychczasowych polskojęzycznych publikacji książkowych, poświęconych starożytnym i średniowiecznym dziejom Kościoła ormiańskiego, który akurat w tym roku obchodzi jubileusz 1700-lecia oficjalnego przyjęcia chrztu. Jej Autor, deklarujący się jako mediewista i pracownik naukowy Zakładu Historii Oświaty i Kultury w Instytucie Historii UJ, potrafił w swej książce, będącej rozprawą habilitacyjną, nie tylko wykorzystać prawie wszystkie dostępne ormiańskie źródła (kroniki, historie, żywoty, synaksaria, księgi liturgiczne) starożytne i średniowieczne (najczęściej w przekładach nowożytnych) oraz niedostępną dotąd w pełni korespondencję Stolicy Apostolskiej z Kościołem ormiańskim tego okresu, ale obiektywnie i bez jakichś ideologicznych uprzedzeń je zinterpretować na tle najnowszej związanej z nimi literatury światowej. Pracą tą chce Autor, jak zaznacza we wprowadzeniu (s. 10), „zapełnić lukę w naszej historiografii, zapoznać z nowszym stanem badań i przybliżyć tę tematykę wszystkim zainteresowanym Kościołami, także studentom teologii, religioznawstwa czy socjologii, którzy po omacku szukają jakichś informacji na ten temat”. Za swój zaś cel stawia sobie „pokazanie związków Kościoła Armenii ze Stolicą Apostolską w średniowieczu” (tamże). Lukę tę i postawiony cel Autor, jak się wydaje, wypełnia z nawiązką, tym bardziej, że jest to pierwsza czysto polska (nie przekład, jak np. D.M. 